\title{
Decadal-Scale Changes in Dissolved-Solids Concentrations in Groundwater Used for Public Supply, Salt Lake Valley, Utah
}

\author{
Concentrations of dissolved solids in groundwater in Salt Lake Valley vary, and the distribution and \\ amounts of these concentrations have changed over time in parts of the principal aquifer.
}

Basin-fill aquifers are a major source of good-quality water for public supply in many areas of the southwestern United States and have undergone increasing development as populations have grown over time. During 2005, the basin-fill aquifer in Salt Lake Valley, Utah (fig. 1), provided approximately 75,000 acre-feet, or about 29 percent of the total amount of water used by a population of 967,000 (Kenny and others, 2009). Groundwater in the unconsolidated basin-fill deposits that make up the aquifer occurs under unconfined and confined conditions (fig. 2).

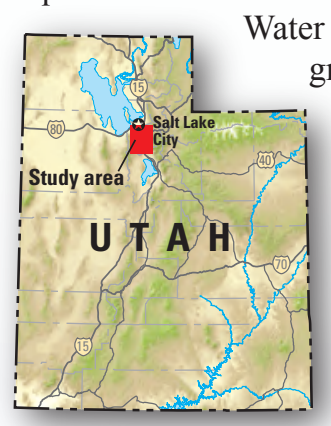

groundwater system is susceptible to near-surface contamination and generally is not used as a source of drinking water. Groundwater for public supply is withdrawn from the deeper unconfined and confined parts of the system, termed the principal aquifer, because yields generally are greater and water quality is better (including lower dissolved-solids

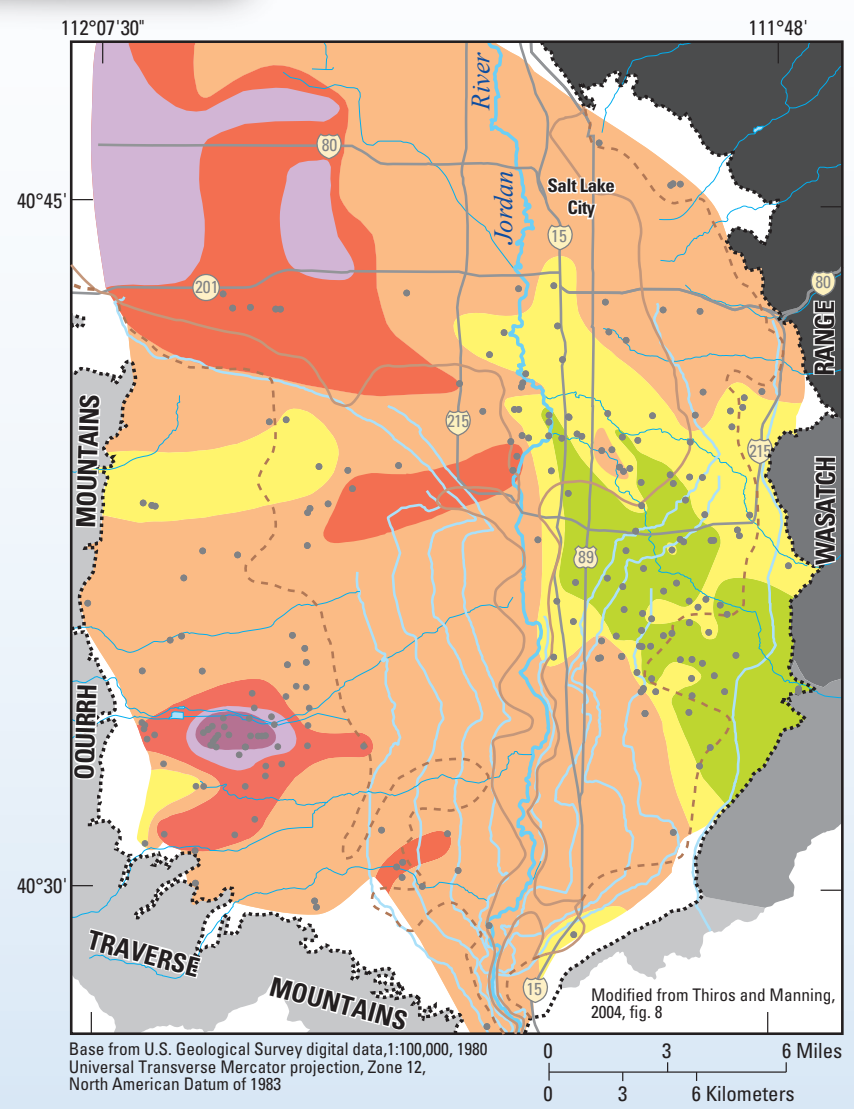

concentrations) than in the shallower parts of the system. Much of the water in the principal aquifer is derived from recharge in the adjacent Wasatch Range (mountain-block recharge) (fig. 2). In many areas, the principal aquifer is separated from the overlying shallow aquifer by confining layers of less permeable, fine-grained sediment that inhibit the downward movement of water and any potential contaminants from the surface. Nonetheless, under certain hydrologic conditions, human-related activities can increase dissolved-solids concentrations in the principal aquifer and result in groundwater becoming unsuitable for consumption without treatment or mixing with water having lower dissolved-solids concentrations. Dissolved-solids concentrations in areas of the principal aquifer used for public supply typically are less than 500 milligrams per liter $(\mathrm{mg} / \mathrm{L})$, the U.S. Environmental Protection Agency (EPA) secondary (nonenforceable) drinking-water standard (U.S. Environmental Protection Agency, 2009). However, substantial increases in dissolvedsolids concentrations in the principal aquifer have been documented in some areas used for public supply, raising concerns as to the source(s) and cause(s) of the higher concentrations and the potential long-term effects on groundwater quality.

\section{Sources and Distribution of Dissolved-Solids Concentrations in Salt Lake Valley Groundwater}

Groundwater in the basin-fill deposits of Salt Lake Valley is characterized by a natural range in dissolved-solids concentration that results primarily from the different sources of water that recharge the aquifer and from water-rock interactions. Anning and others (2007) found that dissolved-solids concentrations in selected basin-fill aquifers across the southwestern United States, including the principal aquifer in Salt Lake Valley, generally increase along groundwater flow paths as water moves from adjacent mountain blocks to lower-lying discharge areas (fig. 2),

\section{EXPLANATION}

Dissolved-solids concentration, in milligrams per liter, 1998-2002

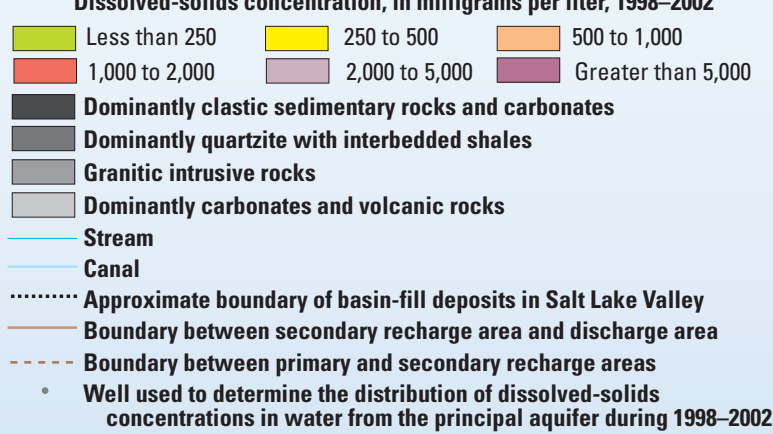

Figure 1. The distribution of dissolved-solids concentrations in water from the principal aquifer in Salt Lake Valley, Utah, 1998-2002, shows that concentrations less than 500 milligrams per liter occur primarily in the east-central part of the valley. 


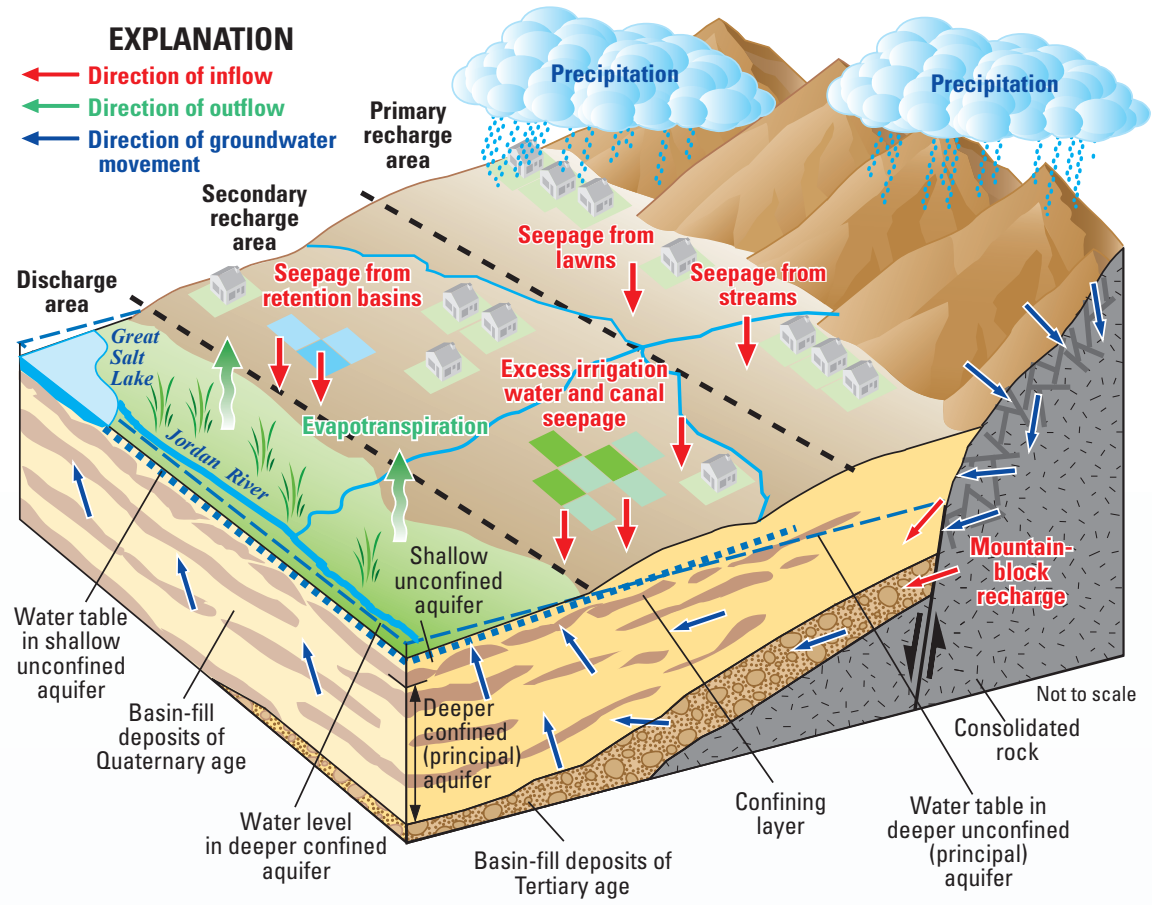

Figure 2. A generalized conceptual model of the groundwater flow system in Salt Lake Valley, Utah, shows that the principal aquifer is unconfined near the mountain front and becomes confined toward the center of the valley.

typically as a result of mineral dissolution within the aquifer. A study by Thiros (2003) to understand the effects of residential land use on water quality in the valley showed that concentrations of dissolved solids in shallow groundwater ranged from 134 to 2,910 mg/L. In Salt Lake Valley, sources of recharge to shallow groundwater include precipitation on the valley floor, seepage of excess water from irrigated fields and urban areas, and seepage from streams, canals, water distribution pipes, sewer lines, storm drains, and retention basins (fig. 2). Concentrations of dissolved solids in water from several of these sources can be increased by runoff of sodium chloride (salt) deicers applied to roads and by evapotranspiration. In addition, water containing a median dissolved-solids concentration of about $1,100 \mathrm{mg} / \mathrm{L}$ (Hely and others, 1971) is diverted from the Jordan River, which flows north to Salt Lake Valley from Utah Lake about 30 miles to the south, into a series of canals (fig. 1) that historically have been used to irrigate crops in parts of the valley. Water diverted from the river has become a significant source of recharge to parts of the shallow aquifer in Salt Lake Valley (Thiros, 2003) and may migrate downward to the underlying principal aquifer in some areas (Thiros and Manning, 2004).

The distribution of dissolved-solids concentrations in the principal aquifer was originally mapped by Hely and others (1971) using data collected mainly from 1964-68, with some analyses from 1932-63. Data collected from 1979-84 (Waddell and others, 1987), 1988-92 (Thiros, 1995), and 1998-2002 (Thiros and Manning, 2004) were used to refine the previous distribution maps of dissolved solids where a change was indicated. Most of the data used to construct these maps were obtained from analyses of samples collected by the U.S. Geological Survey, public water suppliers, and Kennecott Utah Copper Corporation. As shown on figure 1, dissolved-solids concentrations in the principal aquifer in 1998-2002 ranged from less than $250 \mathrm{mg} / \mathrm{L}$ to more than $5,000 \mathrm{mg} / \mathrm{L}$. Areas where dissolvedsolids concentrations are less than $500 \mathrm{mg} / \mathrm{L}$ are primarily in the east-central part of the valley between the Jordan River and the Wasatch Range; much of this area contains groundwater with dissolved-solids concentrations less than $250 \mathrm{mg} / \mathrm{L}$. Groundwater in these areas is recharged primarily along the margin of the valley by snowmelt runoff and subsurface inflow from the Wasatch Range that is low in dissolved solids.

Most of the water in the principal aquifer contains between 500 and 1,000 mg/L dissolved solids (fig. 1), which in many areas is naturally occurring. For example, the basin-fill sediments in the northeastern part of the valley are eroded from shale strata in the adjacent Wasatch Range (fig. 1). Dissolution of minerals in these rocks naturally results in groundwater containing calcium, bicarbonate, and sulfate as major ions and dissolved-solids concentrations greater than 500 $\mathrm{mg} / \mathrm{L}$ (Thiros, 1995). Available data indicate that areas containing groundwater with dissolved-solids concentrations greater than $1,000 \mathrm{mg} / \mathrm{L}$ are primarily in the western part of the valley, west of the Jordan River. In the southern part of the valley where water from some wells has a dissolvedsolids concentration greater than $1,000 \mathrm{mg} / \mathrm{L}$, the groundwater is warmer (Thiros, 1995), less enriched in the stable isotopes of oxygen and deuterium, and is older than water from wells in the northern and eastern parts of the valley (Thiros and Manning, 2004). This possibly indicates that groundwater in the southern part of the valley has undergone deeper circulation and has longer residence times, resulting in increased dissolved-solids concentrations. Areas where dissolved-solids concentrations in the principal aquifer exceed $2,000 \mathrm{mg} / \mathrm{L}$ are in both the southwestern part of the valley, where the oxidation of sulfide ore from the Oquirrh Mountains has resulted in elevated concentrations of dissolved solids, mainly sulfate, and the northwestern part of the valley near the Great Salt Lake, where freshwater mixing with briny pore water in sediments near the lake has resulted in high sodium and chloride concentrations. Most water withdrawn from the principal aquifer in these areas is not suitable for drinking-water use because of undesirable aesthetic qualities such as taste, odor, and appearance.

\section{Changes in Dissolved-Solids Concentrations in Groundwater}

Water-quality data collected by public suppliers to meet Safe Drinking Water Act requirements were accessed from the State of Utah's Safe Drinking Water Information System (SDWIS) database to show long-term changes in dissolved-solids concentrations (fig. 3). Dissolved-solids concentrations in water from some wells in the principal aquifer in Salt Lake Valley have increased over time, while concentrations in others have remained essentially the same or have fluctuated within a relatively small range. Concentrations in some wells have remained relatively stable even when near wells where substantial increases or fluctuations in concentration have taken place (figs. 3A, C,H). Concentrations in water from several wells increased from less than $500 \mathrm{mg} / \mathrm{L}$ to more than $1,000 \mathrm{mg} / \mathrm{L}$ over a 20 -year time span (figs. 3A,H,I). Results of chemical analyses of water samples indicate that much of the increase in dissolved solids for many of the wells corresponds to an increase in chloride concentration (Burden and others, 2009, fig. 10). 

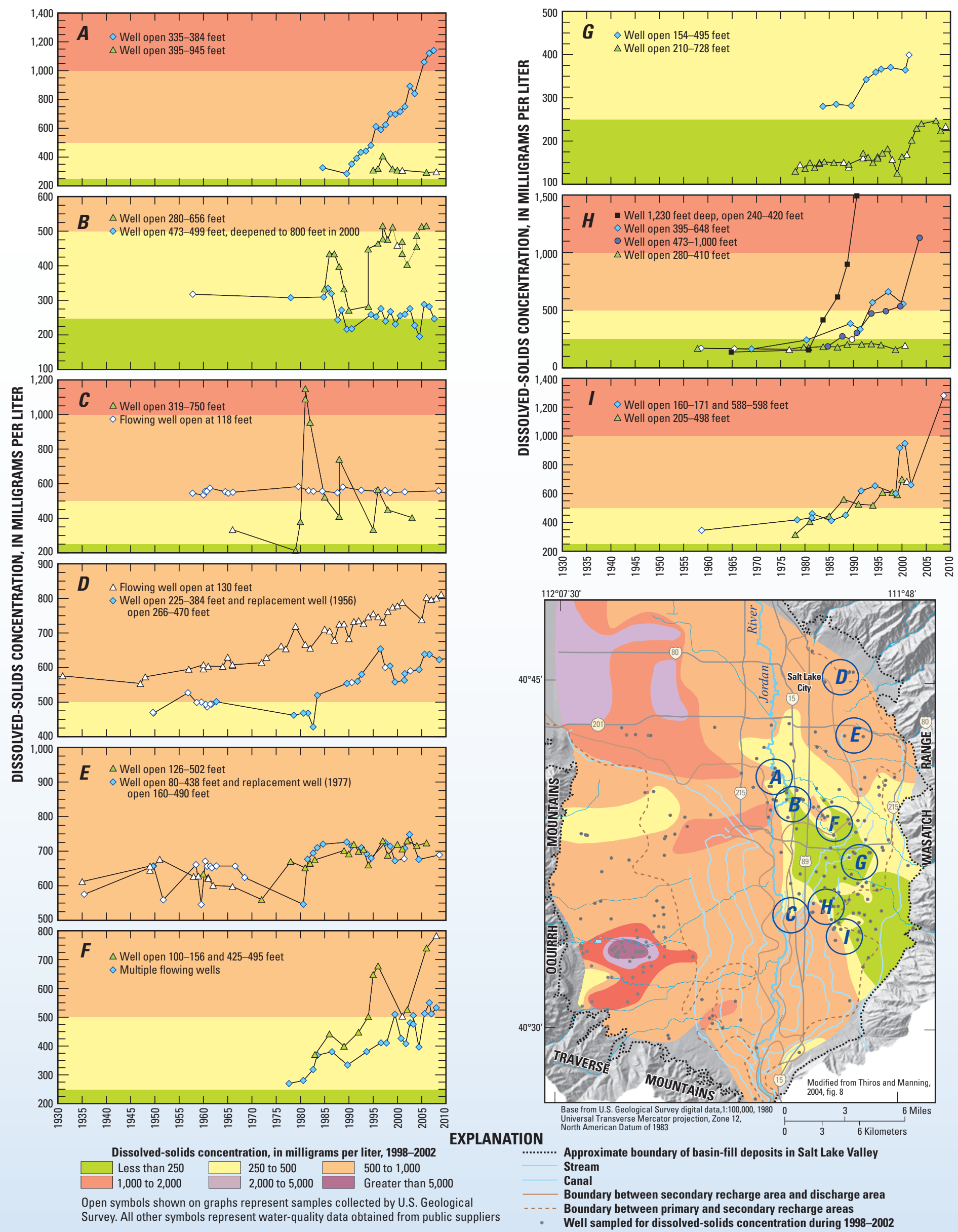

Figure 3. Dissolved-solids concentrations in water from some wells in the principal aquifer in Salt Lake Valley, Utah, have increased to more than 1,000 milligrams per liter. 
Changes in dissolved-solids concentrations in some areas may be caused by downward movement of shallow groundwater to the principal aquifer (Thiros, 2003) (fig. 4). Dissolved-solids concentration in water from a well that has an open interval from 335 to 384 feet below land surface and is located in the northcentral part of the valley near the Jordan River, increased from about $300 \mathrm{mg} / \mathrm{L}$ to almost 1,200 mg/L over an 18-year time span (fig. 3A). In contrast, water from a nearby well that has a longer and deeper open interval (395 to 945 feet below land surface) had a relatively stable concentration (about $300 \mathrm{mg} / \mathrm{L}$ ) during an overlapping 13-year time span (fig. 3A). These relative changes in dissolved-solids concentration suggest that wells having shallower open intervals are more susceptible to downward migration of water containing higher dissolved-solids concentrations than are wells having deeper open intervals. Pumpage from wells may have enabled the downward movement of shallow groundwater in this area where the natural vertical hydraulic gradient is upward (Thiros and Manning, 2004) and may have resulted in increases or fluctuations in dissolved-solids concentrations in water from some wells (figs. 3A,B).

Changes in dissolved-solids concentrations may also be related to pumping intervals and rates. Wells that are pumped only intermittently are less likely to induce water containing higher dissolved-solids concentrations into the wellbore than wells that are pumped continuously, but concentrations in intermittently pumped wells may fluctuate widely if a source of higher dissolved solids is within their capture zone. Likewise, low pumping rates are less likely than high pumping rates to induce water containing higher dissolved-solids concentrations into the wellbore if the water originates farther from the well. For example, fluctuations in dissolved-solids concentration in a well in the south-central part of the valley (fig. 3C) may have resulted from intermittent pumping or variable pumping rates, with water containing higher concentrations moving into the well during increased rates of pumping and water containing lower concentrations entering the well during periods of decreased pumping. In comparison, the dissolved-solids concentration in a nearby low-yield flowing well that was not pumped varies little with time (fig. 3C).

Graphs of dissolved-solids concentrations in some wells in the northeastern part of the valley where concentrations are greater than $500 \mathrm{mg} / \mathrm{L}$ show either a gradual trend of increasing concentration over time (fig. 3D) or no obvious (fluctuating) trend (fig. 3E). The graph of concentrations in samples from a shallow artesian well in this area (fig. 3D) shows a steady increase in dissolved-solids concentration from about $550 \mathrm{mg} / \mathrm{L}$ in the 1930 s and 1940 s to greater than $800 \mathrm{mg} / \mathrm{L}$ in 2009, an increase of about 45 percent. This, in addition to elevated concentrations of nitrate in water from the well and a modern (less than about 50 years old) interpreted groundwater age (Thiros and Manning, 2004), suggests that the source of higher dissolved solids could be water affected by human activities at land surface near the well. Detectable concentrations of pesticides (mainly atrazine and its degradate deethylatrazine), chlorofluorocarbons (refrigerants), volatile organic compounds (mainly the chlorination by-product chloroform), and elevated concentrations of nitrate in water from some public-supply wells in other areas in the eastern part of the valley may also indicate downward movement of water from the surface from an anthropogenic source, such as irrigation and urban runoff (Thiros and Manning, 2004). Although these constituents are not a significant component of the total dissolved solids, their occurrence in the principal aquifer suggests that groundwater containing high concentrations of dissolved solids may readily move from the shallow aquifer to the principal aquifer.

Increases in dissolved-solids concentrations in water from some wells in the discharge area (fig. 3F) and in the secondary recharge area of the valley (fig. 3G) where dissolved-solids concentrations are typically less than $500 \mathrm{mg} / \mathrm{L}$, also may have resulted from downward movement of water from the shallow aquifer to the principal aquifer. Groundwater ages in these areas have been shown to be anomalously young when compared with water from other wells located a similar distance from the mountain front (Thiros and Manning, 2004, fig. 22). The principal aquifer is more susceptible to contamination from surface sources in the secondary recharge area than in the discharge area because confining layers are discontinuous and a downward gradient exists (fig. 2). This downward movement of water into the principal aquifer could be substantially enhanced by pumping. In contrast, thicker and more continuous confining layers and an upward hydraulic gradient impede the downward movement of water in the discharge area. However, where pumping of wells has the potential to reverse the water-level gradient between the shallow and deeper aquifers, wellbores may serve as pathways through the confining layers (Landon and others, 2009) and allow water with higher concentrations of dissolved solids to move downward (fig. 4).

A graph of dissolved-solids concentrations over time in water from three wells in the southeastern part of the valley

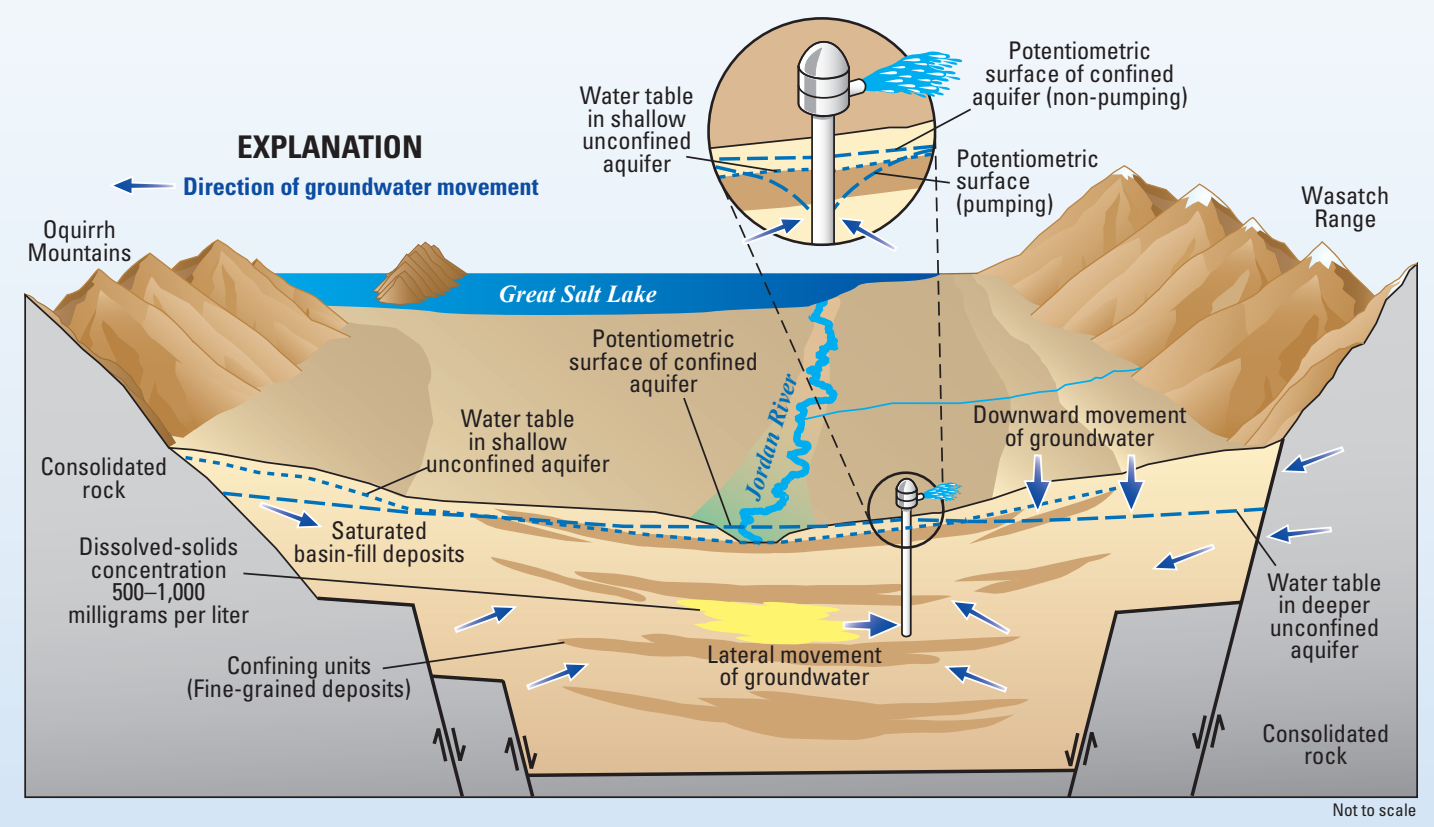

Figure 4. Water containing high concentrations of dissolved solids has the potential to move downward from the shallow unconfined aquifer to the principal aquifer in Salt Lake Valley, Utah. 

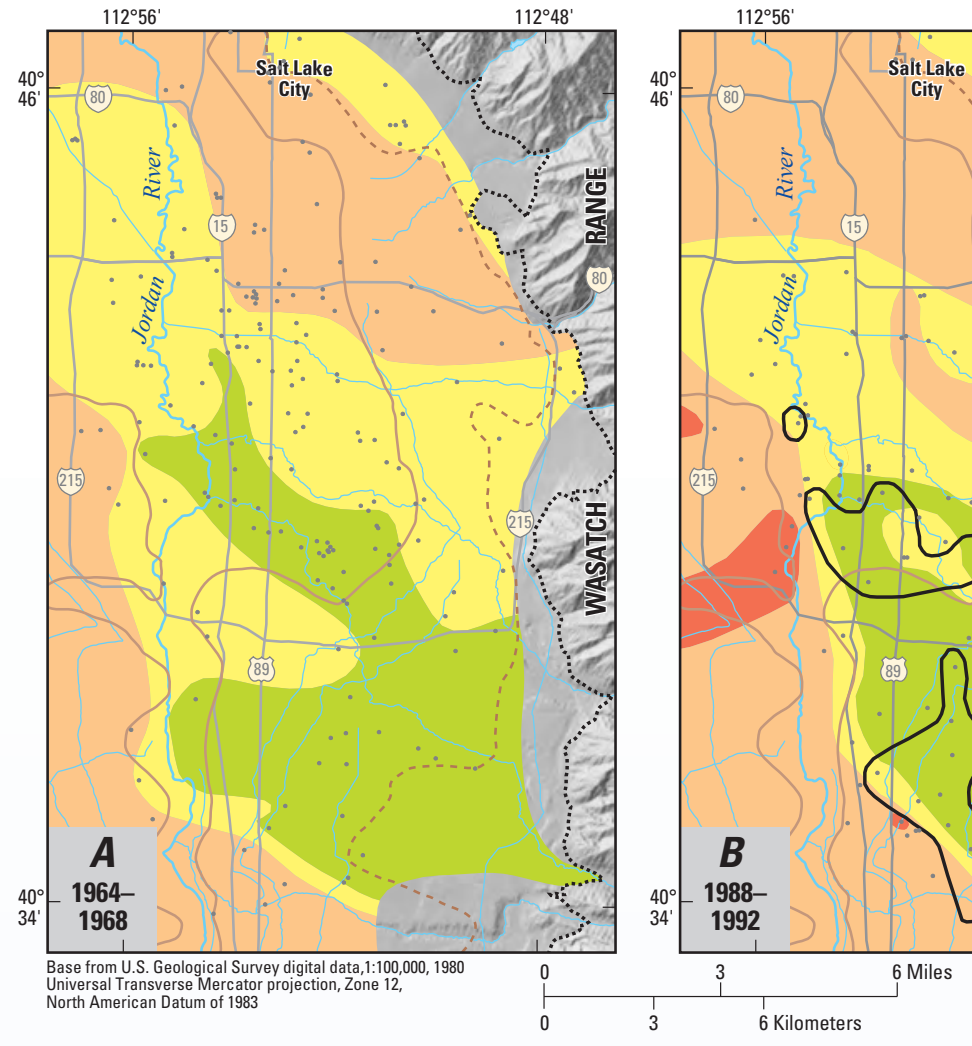

Figure 5. The distribution of dissolved-solids concentrations in the principal aquifer in the central and eastern parts of Salt Lake Valley, Utah, has changed from $A, 1964-68$ to $B, 1988-92$ to $C, 1998-2002$.

(near the transition from areas where concentrations are 500 to $1,000 \mathrm{mg} / \mathrm{L}$ to areas where concentrations are less than 500 $\mathrm{mg} / \mathrm{L}$ ) shows substantial increases in concentrations, whereas water from a well located in the adjacent area of good-quality water shows no increase (fig. 3H). Pumping these wells or wells located upgradient from the transition area may have induced water to move laterally into the wellbores (fig. 4) from adjacent areas to the west and southwest where natural concentrations in the principal aquifer are greater than $500 \mathrm{mg} / \mathrm{L}$. Increases in dissolved-solids concentrations in water from other wells in this transition zone (fig. 3I) also may have resulted from lateral movement of groundwater into wellbores.

\section{Changes in the Spatial Distribution of Dissolved- Solids Concentrations in Groundwater}

Increases in dissolved-solids concentrations in the principal aquifer have changed the spatial distribution of dissolved solids since the late 1960s. A comparison of dissolved-solids concentrations in water from wells in the central and eastern parts of Salt Lake Valley during the 1964-68, 1988-92, and 1998-2002 time periods shows an overall reduction in the size of the area where concentrations are less than $500 \mathrm{mg} / \mathrm{L}$ (fig. 5). Dissolvedsolids concentrations that historically were less than $500 \mathrm{mg} / \mathrm{L}$ (fig. 5A) have increased in some areas to between 500 and $1,000 \mathrm{mg} / \mathrm{L}$, particularly in the central part of the valley along the Jordan River corridor (figs. 5B,C). As a result, the area containing water with concentrations of 250 to $500 \mathrm{mg} / \mathrm{L}$ appears to have gradually retreated to the southeast and east. Furthermore, the area in the southeastern part of the valley where dissolvedsolids concentrations are less than $250 \mathrm{mg} / \mathrm{L}$ decreased in size
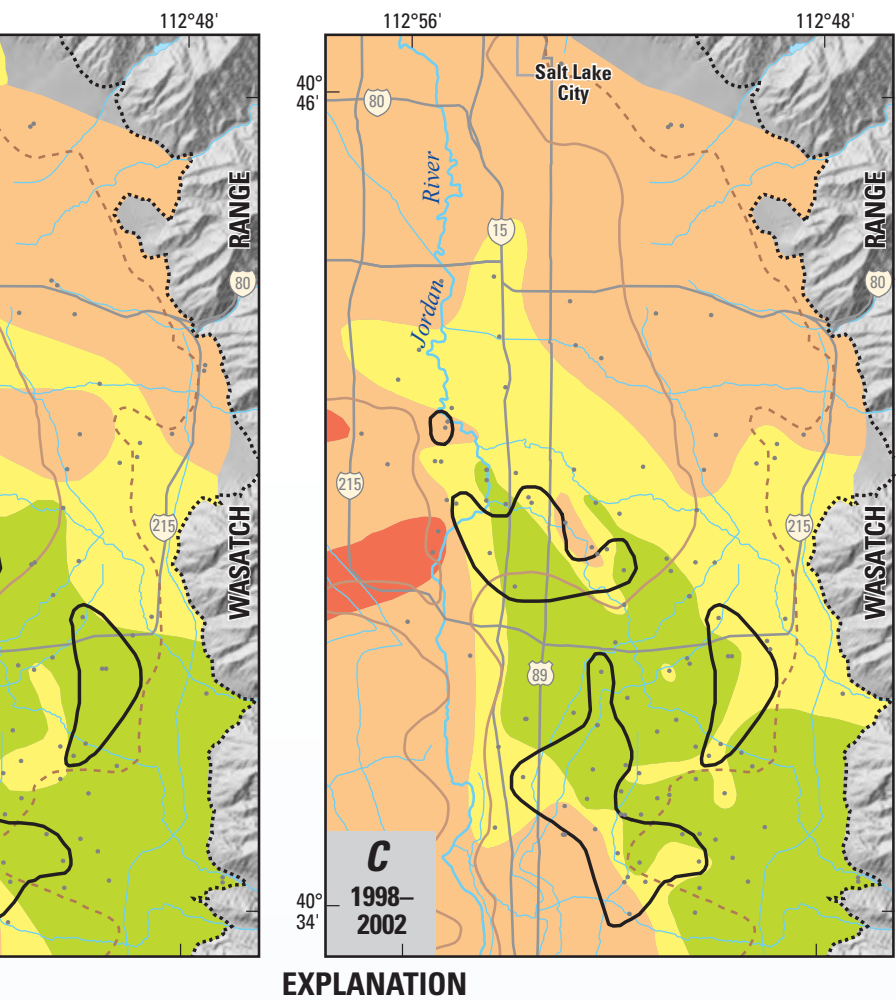

EXPLANATION

Dissolved-solids concentration, in milligrams per liter

Less than $250 \square 250$ to $500 \quad \square 00$ to 1,000 1,000 to 2,000

.......... Approximate boundary of basin-fill deposits in Salt Lake Valley

- Boundary between secondary recharge area and discharge area

Boundary between primary and secondary recharge areas

- Boundary of area where the dissolved-solids concentration in water from more than one well increased 20 percent or more during 1988-2002

Well used to determine the distribution of dissolved-solids concentrations in water from the principal aquifer during 1998-2002

from 1988-92 to 1998-2002 as the area containing concentrations between 250 and $500 \mathrm{mg} / \mathrm{L}$ increased (figs. 5B,C).

Changes in the spatial distribution of dissolved-solids concentrations in the principal aquifer on the east side of the valley are particularly notable in the three areas outlined on figures $5 \mathrm{~B}$ and $\mathrm{C}$. In these areas, the dissolved-solids concentration in water from more than one well increased by 20 percent or more from 1988-92 to 1998-2002. Parts of these areas correspond to areas containing relatively large components of modern (less than about 50 years old) water (Thiros and Manning, 2004, fig. 23). Groundwater withdrawals in these areas may have allowed recently recharged water containing higher concentrations of dissolved solids to move downward into the aquifer tapped by the wells or to move laterally to the wells from adjacent areas in the aquifer that contain water with higher concentrations (fig. 4).

Although changes in dissolved-solids concentrations in water from some wells have been documented over time, accurate representation of the spatial distribution of dissolved-solids concentrations and temporal changes depends on the number, density, location, and availability of the same wells. In general, fewer wells are available for sampling west of the Jordan River than east of the river, and thus, the spatial distribution of dissolved solids is less well represented. In some areas, the same wells were not available for sampling during all time periods and other wells were used that were completed at similar depths. In other areas, no wells completed in the principal aquifer were available for sampling, particularly during the earlier time period (fig. 5A). Spatial representation of changes in 
dissolved-solids concentrations is also influenced by when the wells were sampled, in addition to previously noted well characteristics (depth and open interval) and well effects (pumping). As a result, interpolated boundaries between dissolved-solidsconcentration categories may be more accurately represented in some areas, such as where well density is higher, than in others and from one time period to another.

\section{Effects and Implications of Increasing Dissolved- Solids Concentrations in Groundwater}

The concentration of dissolved solids in groundwater determines its suitability for many beneficial uses. Water that has a concentration less than $500 \mathrm{mg} / \mathrm{L}$ is generally suitable for drinking provided that no other constituents of concern, such as arsenic, prohibit its use. Water that has a concentration greater than $500 \mathrm{mg} / \mathrm{L}$ to about $1,000 \mathrm{mg} / \mathrm{L}$ may have to be treated or blended with other water having lower dissolved-solids concentrations to be suitable for drinking. Water containing a concentration greater than $1,000 \mathrm{mg} / \mathrm{L}$ is generally not used for public supply unless a water supplier can satisfactorily demonstrate that no better water is available (Utah Department of Environmental Quality, 2003), but the water may be used for irrigation, industrial, or commercial applications.

Water containing even moderately high dissolved-solids concentrations can encrust or corrode metallic surfaces, shortening the lifespan of distribution systems, appliances, and other equipment. Corrosion of well casings has been well-documented, especially where high dissolved-solids concentrations are attributed to sodium chloride salts (Spangler and others, 1996). For irrigation users, high dissolved-solids concentrations can result in decreased crop production or crop loss, and thus, decreases in revenue (Anning and others, 2007). For industrial users, excessive dissolved-solids concentrations can cause scaling or precipitation of carbonate minerals, adding costs for maintenance and replacement of equipment. High levels of dissolved solids in groundwater can also limit consumption of water by livestock.

In the eastern part of Salt Lake Valley, areas with dissolvedsolids concentrations less than $250 \mathrm{mg} / \mathrm{L}$ are gradually decreasing in size, while areas with water having concentrations that exceed $500 \mathrm{mg} / \mathrm{L}$ are increasing. Loss of areas containing potable groundwater eventually will cause public suppliers to (1) initiate methods for additional treatment of water, such as reverse osmosis, to reduce dissolved-solids concentrations, (2) seek alternative sources of water that are suitable for drinking, such as water from other basins, (3) seal off well openings in zones of poor-quality water in affected wells where they can be identified, and (or) (4) deepen existing wells or drill additional wells in areas not affected by increasing dissolved-solids concentrations.

Increasing dissolved-solids concentrations in groundwater is an important concern in other areas of the southwestern United States where hydrogeologic conditions similar to those in Salt Lake Valley exist. As populations continue to grow in the Southwest, withdrawals of groundwater will also likely increase to meet increasing demands. Public suppliers and water managers will need to continue or adopt measures to ensure that the effects of well pumping and other human activities will not result in higher dissolved-solids concentrations and degradation of potable water supplies.

\section{References}

Anning, D.W., Bauch, N.J., Gerner, S.J., Flynn, M.E., Hamlin, S.N., Moore, S.J., Schaefer, D.H., Anderholm, S.K., and Spangler, L.E., 2007, Dissolved solids in basin-fill aquifers and streams in the southwestern United States: U.S. Geological Survey Scientific Investigations Report 2006-5315, 168 p., available at http://pubs.usgs.gov/sir/2006/5315/.

Burden, C.B., and others, 2009, Ground-water conditions in Utah, spring of 2009: Utah Division of Water Resources Cooperative Investigations Report No. 50, 119 p., available at http://ut.water.usgs.gov/publications/GW2009.pdf.

Hely, A.G., Mower, R.W., and Harr, C.A., 1971, Water resources of Salt Lake County, Utah: Utah Department of Natural Resources Technical Publication No. 31, 244 p.

Kenny, J.F., Barber, N.L., Hutson, S.S., Linsey, K.S., Lovelace, J.K., and Maupin, M.A., 2009, Estimated use of water in the United States in 2005: U.S. Geological Survey Circular 1344, 52 p., available at http://pubs.usgs.gov/circ/1344/.

Landon, M.K., Jurgens, B.C., Katz, B.G., Eberts, S.M., Burow, K.R., and Crandall, C.A., 2009, Depth-dependent sampling to identify short-circuit pathways to public-supply wells in multiple aquifer settings in the United States: Hydrogeology Journal, accessed August 27, 2010, at http://oh.water.usgs.gov/tanc/pubs/landon_hydrogeology-journal_Oct_2009.pdf.

Spangler, L.E., Naftz, D.L., and Peterman, Z.E., 1996, Hydrology, chemical quality, and characterization of salinity in the Navajo aquifer in and near the Greater Aneth Oil Field, San Juan County, Utah: U.S. Geological Survey Water-Resources Investigations Report 96-4155, $90 \mathrm{p}$.

Thiros, S.A., 1995, Chemical composition of ground water, hydrologic properties of basin-fill material, and ground-water movement in Salt Lake Valley, Utah: Utah Department of Natural Resources Technical Publication No. 110-A, 59 p.

Thiros, S.A., 2003, Quality and sources of shallow ground water in areas of recent residential development in Salt Lake Valley, Salt Lake County, Utah: U.S. Geological Survey Water-Resources Investigations Report 03-4028, 74 p., available at http://pubs.water.usgs.gov/wri034028.

Thiros, S.A., and Manning, A.H., 2004, Quality and sources of ground water used for public supply in Salt Lake Valley, Salt Lake County, Utah, 2001: U.S. Geological Survey Water-Resources Investigations Report 03-4325, 95 p., available at http://pubs.water.usgs.gov/ wri034325.

U.S. Environmental Protection Agency, 2009, Drinking water contaminants, accessed June 12, 2009, at http://www.epa.gov/safewater/ contaminants/index.html.

Utah Department of Environmental Quality, 2003, Utah drinking water standards, accessed October 20, 2009, at http://www.drinkingwater. utah.gov/standards.htm.

Waddell, K.M., Seiler, R.L., and Solomon, D.K., 1987, Chemical quality of ground water in Salt Lake Valley, Utah, 1969-85: Utah Department of Natural Resources Technical Publication No. 89, 56 p.

\section{By Susan Thiros and Larry Spangler}

\section{Additional information about the Southwest Principal Aquifers Water-Quality Assessment can be accessed at} http://water.usgs.gov/nawqa/studies/praq 